\title{
PENGARUH KUALITAS PELAYANAN TERHADAP KEPUASAN KONSUMEN LEMBAGA KURSUS DAN PELATIHAN (LKP) CITRA JELITA DESA WONOREJO KECAMATAN SRENGAT KABUPATEN BLITAR
}

\author{
THE INFLUENCE OF SERVICE QUALITY ON CONSUMER \\ SATISFACTION COURSE AND TRAINING INSTITUTION (LKP) CITRA \\ JELITA WONOREJO VILLAGE, SRENGAT DISTRICT BLITAR DISTRICT
}

\author{
Lu'Lu Ul Maknunah', Endang Astuningtyas ${ }^{2}$ \\ ${ }^{1}$ Universitas Islam Balitar, Blitar, Indonesia \\ ${ }^{2}$ Universitas Islam Balitar, Blitar, Indonesia \\ uul.unisba@gmail.com
}

\begin{abstract}
ABSTRAK
Lembaga Pelatihan Kursus dan Pelatihan Kerja adalah tempat pelatihan yang sangat sering digunakan masyarakat untuk mengasah atau menambah keahlian dan keterampilan. Untuk memenangkan persaingan pada bidang jasa yang berhubungan dengan kepuasaan konsumen maka usaha yang harus diupayakan oleh perusahaan adalah meningkatkan kualitas dalam melayani konsumen.

Penelitian ini memiliki tujuan agar dapat diketahui pengarunya antara kualitas pelayanan dengan kepuasan konsumen pada Lembaga Kursus dan Pelatihan (LKP) Citra Jelita Desa Wonorejo Kecamatan Srengat Kabupaten Blitar. Penelitian yang dilakukan menggunakan penelitian kuantitatif dengan pendekatan deskriptif. Dan hanya terdapat dua variabel yaitu variabel $\mathrm{X}$ yaitu kualitas pelayanan dan variable $\mathrm{Y}$ yaitu kepuasan konsumen. Peneliti menggunakan sampel sejumlah 30 orang yang merupakan konsumen dan peserta didik yang mengikuti LKP Citra Jelita.

Alat analisa yang digunakan yaitu analisa uji parsial atau uji $\mathrm{T}$ dengan taraf signifikasi 0,05. Peneliti menggunakan 2 (dua) data yaitu data primer dan data sekunder yang diperoleh dengan melakukan pengamatan (observation), kuesioner, dokumentasi (documentation), serta studi pustaka (study library). Hipotesa yang digunakan yaitu, H0: tidak ada pengaruhnya antara Kualitas pelayanan dengan kepuasan konsumen. Ha: ada pengaruhnya antara kualitas pelayanan dengan kepuasan konsumen. Agar dapat diketahuo tingkat pengaruh dari hipotesa yang ditetapkan maka peneliti menggunakan regresi linier sederhana serta koefisien determinasi dengan aplikasi statistik yaitu SPSS 18.

Hasl dari penelitian yang dilakukan melalui implementasi persamaan Regresi Linier, memperlihatkan bahwa kualitas pelayanan memiliki pengaruh yang searah yang sama besarnya kepada Kepuasan konsumen. Berdasarkan uji Parsial (T), variabel Kualitas pelayanan menghasilkan nilai 4,630 dan signifikansi $0,000<0,05$, hal ini artinya bahwa $\mathrm{H}_{\mathrm{a}}$ diterima dan $\mathrm{H}_{0}$
\end{abstract}


Lu'lu Ul Maknunah', Endang Astuningtiyas ${ }^{2}$

Pengaruh Kualitas Pelayanan Terhadap Kepuasan Konsumen Lembaga Kursus dan Pelatihan (LKP) Citra Jelita Desa Wonorejo, Kecamatan Srengat, Kabupaten Blitar

ditolak. Dengan demikian, variabel kualitas pelayanan berpengaruh secara positif serta signifikan atas kepuasan konsumen. Hal ini berarti bahwa jika kualiatas layanan semakin maksimal, maka akan meningkatkan kepuasan konsumen.

Kata Kunci : Kualitas Pelayanan, Kepuasan Konsumen

\section{ABTRACT}

Training Institute Courses and Job Training is a place of training that is very often used by the community to hone or add expertise and skills. To win the competition in the field of services related to consumer satisfaction, the business that must be pursued by the company is to improve the quality in serving consumers.

This study aims to determine the effect between service quality and customer satisfaction at the Citra Jelita Course and Training Institute (LKP) in Citra Jelita, Wonorejo Village, Srengat District, Blitar Regency. Research conducted by researchers is based on quantitative research with a descriptive approach. And there are only two variables, namely variable $X$, namely service quality and variable $Y$, namely customer satisfaction. The researcher used a sample of 30 people who were consumers and students who took part in the Citra Jelita LKP.

The analytical tool used is a partial test analysis or $T$ test with a significance level of 0.05. Researchers used 2 (two) data, namely primary data and secondary data obtained by conducting observations, questionnaires, documentation, and study libraries. The hypothesis used is, HO: there is no effect between service quality and customer satisfaction. Ha: there is an influence between service quality and customer satisfaction. In order to know the level of influence of the established hypothesis, the researchers used simple linear regression and the coefficient of determination with the statistical application of SPSS 18.

The results of the research conducted through the implementation of the Linear Regression equation, show that the quality of service has the same unidirectional influence on consumer satisfaction. Based on the partial test $(T)$, the service quality variable produces a value of 4.630 and a significance of $0.000<0.05$, this means that Ha is accepted and $\mathrm{HO}$ is rejected. Thus, the service quality variable has a positive and significant effect on customer satisfaction. This means that if the service quality is maximized, it will increase customer satisfaction.

Keywords: Service Quality, Consumer Satisfaction

\section{PENDAHULUAN}

Untuk memenangkan persaingan pada sektor jasa sangat berhubungan erat dengan kepuasan konsumen, satu diantara beberapa upaya yang bisa dilaksanakan yaitu dengan meningkatkan kualitas pelayanan. Kualitas pelayanan yang diinginkan konsumen yaitu tersedianya saran yang mencukupi, memberikan layanan yang maksimal, suasana yang nyaman, jaminan rasa aman, tenang serta merasakan kepuasan sehingga perusahaan perlu melakukan perencanaan agar dapat memberikan kualitas pelayanan yang optimal untuk saat ini dan mendatang. Usaha meningkatkan mutu pelayanan terlihat efektifitasnya jika dalam keseharianya perusahaan menjadikan mutu layanan sebagai tujuah, yang diawali dari pemimpinnya sampai dengan karyawan atau pelaksana jasa. 


\section{PUBLICIANA : JURNAL ILMU SOSIAL DAN ILMU POLITIK \\ VOLUME 14, NO 02}

ISSN : 1979 - 0295 / E-ISSN : $2502-7336$

Fakta yang harus dihadapi perusahaan spesifiknya bidang jasa, bahwa kualitas pelayanan merupakan sebuah kewajiban untuk tetap berhasil, baik pada tingkatan operasional ataupun strategi. Akan tetapi, saat ini tidak sedikit perusahaan (tidak terkecuali perusahaan bidang jasa) yang berpendapat bahwanya perusahaan bertujuan untuk memberikan kepuasaan pada konsumen. Walaupun pendekatan dalam implementasinya berbeda-beda. Contohnya seperti mengatakan bahwa, "memberi segalanya yang diinginkan konsumen", "pembeli adalah raja", "puasnya konsumen merupakan tujuan kami", dan lain-lainnya.

Kondisi ini bukan hanya dialami pada bagian swasta, namun juga dialami oleh lembaga pemerintahan. Saat ini perusahaan semakin sadar bahwasannya layanan dan rasa puas konsumen adalah faktor krusial sebagai upaya untuk mempertahankan bisnisnya dan memenangkan persaingan. Akana tetapi untuk terwujudnya kepuasan konsumen dengan menyeluruh tidaklah mudah. Ini dikarenakan perusahaan menghadapi pelanggan yang yang tidak sama pada tiap-tiap masanya. Saat ini konsumen sudah semakin 'terdidik' dan mengetahui akan haknya. Maka dari itu, terdapat beberapa pendapat para ahli pemasaran yang memaparkan bahwa tidak realistis jika sebuah perusahaan berharap pelangganya tidak mendapatkan keuasan. Tentunya setiap perusahaan wajib mengusahakan untuk meminimalisir rasa tidak puas yang didapatkan konsumennya dengan memberi layanan hair demi hari yang optimal. Selain itu, secara bersamaan perusahaan juga butuh memberikan perhatian kepada pelanggan yang tidak merasakan kepuasan.

Di jaman globalisasi ini, semakin banyak dan beragam produk maupun jasa yang bersaing pada satu pasar, hal ini dampak dari keterbukaanya pasar. Maka terjadi persaingan diantara perusahaan agar kebutuan konsumen dapat terpenuhi dan memberi rasa puas kepada konsumen dengan optimal. Hal ini dikarenakan pada dasarnya suatu bisnis bertujuan untuk mewujudkan kepuasan konsumen. Satu dari beberpa aktivitas yang dapat dilakukan untuk memberikan rasa puas kepada konsumen yaitu melalui pemberian layanan yang maksimal kepada konsumennya. Fakta ini dapat terlihat, bahwasannya terdapat hal-hal yang diperhatikan dalam memberikan rasa puas bagi konsumen diantaranya nilai total konsumen yakni nilai produk, nilai layanan, nilai personal, nilai citra, dan biaya total konsumen yang diantaranya biaya moneter, biaya waktu, biaya tenaga, serta biaya pikiran (Kotler, 2000).

Melalui kualitas layanan yang optimal dalam perusahaan akan mewejudkan kepuasan pada konsumen. Sesudah konsumen merasakan kepuasan dengan layanan yang diterima, maka konsumen akan melakukan perbandingan kepada layanan yang diterima. Jika konsumen merasakan kepuasan, maka konsumen selanjtunya membeli secara berulang dan mereferensikan pada orang yang lain agar membeli juga di tempat yang sama dengannya. Maka dari itu perusahaan perlu memikirkan betapa penting layanan konsumen dengan lebih mendalam melaui pemberian kualitas pelayanan, hal ini dikarenakan semakin dipahami bahwasannya kepuasan pelanggan adalah faktor krusila sebagai upaya untuk mepertahakan bisnin untuk dapat bersaing (Tjiptono, 2004).

Kabupaten Blitar merupakan satu diantara beberapa kabupaten di Jawa Timur yang berperan penting untuk menjadi pusat pemerintahan serta administratif, pusat bisnis, pendidikan dan kebudayaan. Berdasarkan data dari Disnaker Kabupaten Blitar memiliki Lembaga Kursus dan Pelatihan (LKP) sejumlah 40 LKP. LKP terus berkembang tercermin pada kebijakan pemerintah yang mendukung melalui paket kebijaksanaan atau memberikan paket pelatihan bagi warga, yang semuanya untuk memberi dukungan pada LKP di Kabupaten Blitar agar dapat bertumbuh dan berkembang pada cakupan yang lebih luas. Kecamatan Srengat berada di jalur 
Lu'lu Ul Maknunah', Endang Astuningtiyas ${ }^{2}$

Pengaruh Kualitas Pelayanan Terhadap Kepuasan Konsumen Lembaga Kursus dan Pelatihan (LKP) Citra Jelita Desa Wonorejo, Kecamatan Srengat, Kabupaten Blitar

perhubungan antaratiga Kabupaten yaitu Kabupaten Malang dan Kediri dan Kabupaten Tulungagung.

Lembaga Kursus Pelatihan Kerja Swasta atau disingkat dengan LKP bemberikan berbagai layanan pelatihan yang dapat menambah keahlian serta keterampilan untuk peserta pelatihan. Begitu juga LKP Citra Jelita adalah Lembaga yang memberikan pelatihan kerja yang telah memiliki nama baik di Kecamatan Serengat, Kabupaten Blitar. LKP ini memiliki berbagai macam jurusan pelatihan yaitu tata kecantikan rambut, tata kecantikan kulit, tata rias pengantin serta hantaran. LKP swasta wajib selalu mewujudkan apa yang dibutuhkan dan memuaskan para pelanggan dengan memberikan layanan yang optimal sehingga dapat memuaskan pelanggan dan akan memberikan rekomendasi kepada orang yang lain.

Berdasarkan situasi dan berkembangnya perindustrian yang pesat di Blitar pada khususnya dan di Jawa Timur pada umumnya, maka dibutuhkan tenaga sektor jasa dengan jumlah yang besar, dan mempunyai keahlian serta ketrampilan yang menjadi kebutuhan dunia kerja, salah satunya dengan Lembaga Kursus dan Pelatihan Kerja. LKP memberikan berragam pelatihan kerja yang dapat menambah keahlian dan keterampilan untuk peserta pelatihan maupun calon pekerja.

Lembaga Pelatihan Kursus dan Pelatihan Kerja merupakan tempat pelatihan yang sangat sering digunakan masyarakat agar agar dapat terasah atau bertambah keahlian dan keterampilan peserta pelathian. Peserta pelatihan umumnya adalah dari dalam Kabupaten dan Kota Blitar, namun juga tidak sedikit peserta pelatihan yang berasal di luar Kabupaten dan Kota Blitar, diantaranya Kediri, Tulungagung serta kabupaten atau kota yang lain sekitar Keabupaten Blitar. Kepuasan Konsumen menjadi tujuan dalam LKP karena keberhasilan konsumen setelah mengikuti LKP akan membawa dampak positif baik bagi LKP Citra Jelita maupun masyarakat pada umumnya.

Dari pemaparan diatas, maka peneliti mempunyai ketertarikan untuk meneliti terkait "Pengaruh Kualitas Pelayanan Terhadap Kepuasan Konsumen Lembaga Kursus dan Pelatihan (LKP) Citra Jelita Desa Wonorejo Kecamatan Srengat Kabupaten Blitar”.

\section{KERANGKA TEORI \\ Kualitas Pelayanan}

Pelayanan yang optimal mungkin pernah dirasakan oleh seseorang yang membuat berkesan dan menginginkan dapat mendapatkannya kembali dan sesering mungkin. Akan tetapi kebalikannya seseorang juga pernah merasakan pelayanan yang sangat buruh bahkan mengakibatkan seseorang menjadi emosional karenanya. Namun terkada juga sesorang pernah mengalami pelayanan yang tidak buruk dan juga tidak merasa puas atau biasa saja.

Pelayanan merupakan sebuah respon dan perbuatan maupun cara memberikan layanan kepada orang lain agar dapat terpenuhi yang dibutuhkan dan diinginkannya. Tingkatan kepuasan pelanggan terhadapt sebuah layanan bisa terukur melalui perbandingan diantara apa yang menjadi keinginan terhadap kualitas layanan yang didapatkan ataupun dirasakan.

Untuk memberikan penjelasan mengenai bisnis jasa, membutukan sebuah strategi pemasaran. Akan tetapi, sebelum ditentukan strategi pemasaran yang dipakai, harus memperhatikan bahwasannya strategi pemasaran jasa yang digunakan tidak sama dengan strategi untuk produk ataupun barang. Bisnis jasa memiliki kecenderungan lebih kepada memberi pelayanan pada pelanggan melalui hubungan secara langsung, maka dari itu bisnis jasa ukuran kesuksesa strateginnya melalui tingkat kepuasan yang disapatkan oleh pelanggan. 


\section{PUBLICIANA : JURNAL ILMU SOSIAL DAN ILMU POLITIK \\ VOLUME 14, NO 02}

ISSN : 1979 - 0295 / E-ISSN : $2502-7336$

Ukuran kualitas pelayanan pada pendekatan Servqual, berdasarkan skala multi item yang disusun dalam pengukuran terhadap apa yang diharapkan dan yang dipersepsikan oleh konsumen, dan jaeak antara kedua varibel tersebut pada ukuran-ukuran baku kualitas jasa. Dalam penelitian yang dilakukan oleh Parasuraman pada tahun 1985, terdapat 10 (sepuluh) dimensi utama dalam mengukur sebuah pelayanan, diantaranya:

1. Bukti fisik, tampilan sarana fisik, peralatan, staf dan materi komunikasi.

2. Reliabilitas, kapasitas dalam memberi pelayanan yang diinginkan dengan keakuratan dan keandalan.

3. Daya tanggap, kesanggupan untuk memberikan bantuan kepada konsumen dan memberi layanan secara cepat.

4. Keandalan, domain keterampilan serta pengetahuan yang diperlukan untuk meberi layanan yang diperlukan oleh konsumen.

5. Kesopanan, tindakan santun, menghormati, kepedulian dan ramah dari para karyawan di garis depan.

6. Kredibilitas, skejujuran dan amanah.

7. Keamanan, bebas bahaya, risiko maupun keraguan.

8. Akses, kenyamanan dalam berhubungan dan ditemukan.

9. Komunikasi, memberikan informasi kepada pelanggan menggunakan bahasa yang dapat dipahami, serta mau untuk mendengar saran dan keluhan konsumen.

10. Kemempuan memahami pelanggan, untuk memahami pelanggan dan apa yang dibutuhkannya (Tjiptono \& Chandra, 2006)

Selanjutnya pada penelitian berikutnya terdapat tiga ahli (Parasuraman et al., 1988) yang memodivikasi dari 10 (sepuluh) dimensi tersebut untuk disempurnakan dan dirangkum. Untuk dimensi keandalan, kesopanan, kredibilitas, serta keamanan dirangkum dalam kesatuan menjadi jaminan (assurance). Kemudian untuk akses, komunikasi, dan kemampuan mengerti pelanggan dimasukkan kedalam empati (empathy). Maka, ada lima dimensi pokok dari kualitas pelanggan yaitu:

1) Bukti fisik (tangibles), diantaranya sarana fisik, perlengkapan pegawai, serta alat untuk berkomunikasi.

2) Reliabilitas (reliability), yaitu kapasitas untuk memberi pelayanan yang tepat waktu, akurat dan memberikan rasa puas.

3) Daya tanggap (responsiveness), yakni pegawai berkeinginan untuk meberikan bantuan kepada konsumen dan melayani dengan responsif.

4) Jaminan (assurance), meliputi pengetahuan, keahlian, sikap sopan, dan sifat pegawai yang bisa dipercaya; terbebasnya dari bahaya, risiko maupun kebimbangan.

5) Empati (empathy), mencangkup mudah untuk terjalinnya interaksi, komunikasi dengan baik, perhatian, dan memahai apa yang dibutuhkan konsumen.

Maka dari itu perusahaan harus dapat mengelola kualitas pelayanan (service quality) agar bisa mendapatkan serta membuat konsumen tetap bertahan. Selain itu, perusahaan diharuskan mampu mewujudkan apa yang dirasakan dan dialami pelanggan menjadi menyenangkan. Kemudian, jika terdapat pelanggan yang menyampaikan keluhannya, anggap saja itu merupakan keadaan yang menjadi kesempatan perusaan untuk menjalankan perbaikan terhadap jasanya (service recovery). Pelanggan yang mengeluh merupakan hadiah dan bukan sebauh ancaman. 
Lu'lu Ul Maknunah', Endang Astuningtiyas ${ }^{2}$

Pengaruh Kualitas Pelayanan Terhadap Kepuasan Konsumen Lembaga Kursus dan Pelatihan (LKP) Citra Jelita Desa Wonorejo, Kecamatan Srengat, Kabupaten Blitar

Keluhan pelanggan dapat berubah menjadi pelanggan yang memiliki loyalitas apabila yang menjadi keluhannya dapat diatasi dengan baik.

Konsumen sekarang ini sulit merasakan kepuasan, hal ini dikarenakan pelanggan sudah makin cerdas, lebih menyadari harga, menuntut, tidak mudah memberikan maaf dan banyak pesaing yang mendekati dengan penawaran yang sama bahkan lebih baik. Namun prinsipnya, perusahaan harus dapat memberikan kepuasaan dan perhatiannya kepada pelanggan agar terjadi peningkatan pada performa bisnisnya.

\section{Faktor-faktor yang Mempengaruhi Kualitas Pelayanan}

Kualitas layanan yang diberikan oleh perusahaan dipengaruhi oleh beberapa aspek. Menurut (Abdullah \& Rozario, 2009), kualitas pelayanan dipengaruhi oleh harapan, kualitas proses serta kualitas hasil. Aspek lain yang juga mempengaruhinya yaitu kualitas fungsional dan kualitas secara teknis (Javadein et al., 2008). Menurut (Sureshchandar et al., 2002)) terdapat 5 (lima) faktor kualitas pelayanan yang krusial jika dilihat dari sisi pelanggan, diantaranya:

a) Layanan pusat atau produk layanan (konten layanan).

b) Elemen Manusia dalam penyediaan layanan, seperti keandalan, kapasitas respons, jaminan, empati dan peningkatan layanan.

c) secara sistematis dengan menyediakan elemen non-manusia, seperti proses, prosedur, sistem dan teknologi yang membuat layanan sempurna.

d) Layanan Bukti Fisik. Seperti perlengkapan, tanda, penampilan karyawan dan lingkungan fisik yang dibuat oleh manusia di sekitar layanan.

e) Tanggung jawab sosial, perilaku etis penyedia layanan.

Perusahaan membutuhkan tanggung jawab dari pegawai dan bantuan dari seluruh tingkatan manajemen agar tercapai kualitas layanan yang terbaik. Maka dari itu pihak perusahaan diharuskan mencermati seluruh aspek-aspek penting didalam menerapkan ataupun mencapai kualitas pelayanan. (Ariani, 2003) berpendapat bahwa kualitas pelayanan yang baik bisa tercapai jika 8 (delapan) elemen-elemen berikut dapat dipenuhi, diantaranya:

a) Fokus pada pelanggan dengan menyediakan apa yang diinginkan oleh konsumen agar merasakan kepuasan.

b) Komitmen jangka panjang, sehingga semua staff ingin melakukan hal yang sama dengan terlibat sepenuhnya pada proses yang ada.

c) Kepemimpinan serta dorongan pimpinan tertinggi, melalui pemberian dukungan tenaga, pemikiran, rencana strategis, gaya dan peningkatan berkelanjutan.

d) Memberdayakan seluruh staf dan tim kerja melalui dukungan keikutsertaan semua staf agar tercapai tujuan, termasuk perbaikan dan pemecahan masalah.

e) Komunikasi yang efektif melalui pengdaan jalinan komunikasi baik dengan formal ataupun informal serta komunikasi horizontal ataupun horizontal.

f) Kepercayaan dan analisa proses statistik, yang dimungkinkan untuk organisasi melaksanakan pembenahan, penetapan prioritas dan evaluasi kemajuan yang telah tercapai.

g) Komitmen untuk memperbaiki melalui penciptaan kesadaran agar terjadi pembenahan melalui pendidikan dan pelatihan staf.

h) Mendorong adanya penghargaan yang tidak berbentuk gaji, akan tetapi apresiasi dengan dipuji, didukung saran dan kritikan yang memotivasi.

Peneliti memandang bahwa LKP merupakan satu diantara berberpa perusahaan yang bergerak pada sektor jasa yang harus dapat memberikan jaminan kualitas pelayanan dengan langsung ataupun tidak langsyng yang didapatkan oleh pelanggan. Aspek sumber daya manusia 


\section{PUBLICIANA : JURNAL ILMU SOSIAL DAN ILMU POLITIK \\ VOLUME 14, NO 02}

ISSN : 1979 - 0295 / E-ISSN : $2502-7336$

(SDM) yang menyediakan jasa adalah komponen paling krusial pada penentuan tingkatan kepuasan pelanggan, dikarenakan memiliki hubungan langsung dengan pelanggan dan memilik pengaruh terhadap nilai akhir pelanggan pada tingkat kepuasan ataupun tingkat tidak puas pelanggan (Stanton \& Gauss, 1994). Pelanggan mau tidak mau, memiliki kesadaran ataupun tidak terhadap sebuah persepsi kepada perusahaan yang memberikan pelayanan. Jika SDM yang memberikan pelayanan diberikan persepsi positif serta sesuai dengan diinginkan, maka pelanggan merasakan kepuasaan dan begitu juga kebilkannya (Jhons, 1992)

\section{Karakteristik Kualitas Pelayanan}

Menurut pendapat (Tjiptono \& Chandra, 2011) jasa memiliki empat karakter pokok, diantaranya:

a. Tidak berwujud (Intangibility), jasa yaitu tidak nyata, berbeda dengan barang fisik.

b. Tidak terpisahkan (Inseparability), bisanya jasa yang diperoleh dan didapatkan di masa yang bersamaan, kemudian jika diinginkan oleh seseorang agar diberikan pada orang lain, maka orang tersebut tetap bagian dari jasa itu.

c. Bervariasi (Variability), sasa sangat variatif, karena bergantung pada siapa, kapan serta di mana jasa itu tersedia.

d. Mudah dilenyapkan (Perishability), jasa yang tidak tersimpan, tidak memiliki daya tahan.

\section{Strategi Meningkatkan Kualitas Pelayanan}

(Tjiptono, 2012) berpendapat bahwa ada faktor-faktor yang menjadi pertimbangan untuk pengingkatan kualitas pelayanan, diantaranya:

1) Melakukan identifikasi determinan utama kualitas pelayanan, tiap-tiap perusahaan yang menyediakan pelayanan diharuskan dapat memberikan pelayanan dengan kualitas paling optimal pada pelanggan.

2) Mengelola ekspektasi pelanggan, tidak sedikit perusahaan yang memiliki upaya untuk menarik perhatian konsumen melalui bermacam-macam cara, salah satunya yaitu melebihkan janji, hal ini bisa menjadi bumerang bagi perusahaan jika tidak tepenuhi apa yang dijanjikannya.

3) Terkelola bukti kualitas pelayanan yang memiliki tujuan agar dapat diperkuat penilaian kosumen selama dan setelah pelayanan diberikan.

4) Mendidik konsumen mengenai pelayanan yang memiliki tujuan afa dapat diwujudkan proses menyampaikan serta mengkomunikasikan pelayanan dengan efektifitas dan efisiensi.

5) Pertumbuhan budaya kualitas melalui dilaksankannya komitmen secara keseluruhan melalui seluruh tim dari yang pucuk pimpinan hingga yang paling rendah. Faktor-faktor yang bisa menjadi penghambat tetapi juga bisa melancarkan pembangunan kualitas pelayanan, diantaranya:

a) Sumber daya manusia, contohnya dalam hal menyeleksi pegawai, melatih pegawai, penjelasan jobdesk, dan lain-lainnya.

b) Organisasi atau struktur, mencakupi intergrasi maupun koordinasi diantara fungsi-fungsi serta struktur laporan.

c) Pengukuran (measurement), adalah mengevaluasi performa dan keluhan serta rasa puas dari pelanggan.

d) Pendukung sistem, merupakan aspek-aspek teknologi misalkan komputer, sistem, basis data, dan teknis lainnya. 
Lu'lu Ul Maknunah', Endang Astuningtiyas ${ }^{2}$

Pengaruh Kualitas Pelayanan Terhadap Kepuasan Konsumen Lembaga Kursus dan Pelatihan (LKP) Citra Jelita Desa Wonorejo, Kecamatan Srengat, Kabupaten Blitar

e) Pelayanan, mencangkup pengelolaan keluhan pelanggan, peralatan manajemen, peralatan advertensi atau penjualan.

f) Komunikasi internal, meliputi prosedur serta kebijakan dalam operasional.

g) Komunikasi eksternal, meliputi pemberian edukasi pada konsumen, pengelolaan ekspektasi konsumen, serta membentuk citra positif perusahaan.

6) Terciptanya otomatisasi kualitas (automating quality) untuk menyelesaikan permasalahan dalam hal berkurangnya SDM yang ada di perusahaan. Tetapi dibutuhkannya perhatian pada elemen-elemen sentuhan manusia (high touch) dan aspek-aspek yang membutuhkan otomatisasi (high tech).

7) Tindak lanjut terhadap pelayanan yang dibutuhkan agar dapat diperbaiki elemen-elemen lpelayanan yang tidak memuaskan serta mempertahankan yang sudah baik.

8) Pengembangan sistem informasi kualitas pelayanan (service quality information system) yang merupakan sistem yang dipakai oleh perusahaan melalui pelaksanaan penelitian terkait data.

\section{Kepuasan Konsumen}

Kotler dalam (Tjiptono \& Chandra, 2011) berpendapat bahwa kepuasan konsumen merupakan tingkatan apa yang dirasakan konsumen sesudah melakukan perbandingan performa yang di persepsikan dengan apa yang diinginkan dan diharapkan. (Kotler et al., 2009) menambahkan bahwa kepuasan (satisfaction) merupakan rasa kesenangan maupun kekecewaan konsumen yang muncul dikarenakan melakukan perbandingan performa dari hasil merasakan produk dengan apa yang dinginkan dari produk tersebut. Apabila kinerjanya tidak berhasil memenuhi keingiinan yang dihaeapkan, maka konsumen akan merasakan ketidak puasan. Sebaliknya jika kinerja selaras dengan yang diinginkan, maka konsumen tersebit akan merasakan kepuasan. Apabila kinerja melampaui harapan konsumen, maka konsumen akan sangat puas ataupun senang.

Oxford Advanced Learner's Dictionary (Tjiptono \& Chandra, 2011) mendefinisikan kepuasan adalah "the positive sentiment that you have when you accomplished something or when something that you needed to happen does occur and the demonstration of satisfying a need or want".

Dari pengertian tersebut maka kesimpulannya yaitu kepuasan konsumen adalah sikap, nilai dan tanggapan emosional yang diperlihatkan oleh pelanggan sesudah membeli atau mengkonsumsi yang diperoleh dari membandingkan kasan terhadap peforma aktual kepada sebuah produk dan apa yang diharapkan, serta mengevaluasi kepada apa yang dialami dari mennggunakan produk maupun jasa tersebut. 
PUBLICIANA : JURNAL ILMU SOSIAL DAN ILMU POLITIK

VOLUME 14, NO 02

ISSN : 1979 - 0295 / E-ISSN : $2502-7336$

\section{Strategi Kepuasan Pelanggan}

Fornell yang dikutip oleh (Tjiptono \& Chandra, 2011) berpendapat dalam tiap-tiap perusahaan melakukan penerapan strategis bisnis kombinasi, yaitu strategi offensive dan defensive.

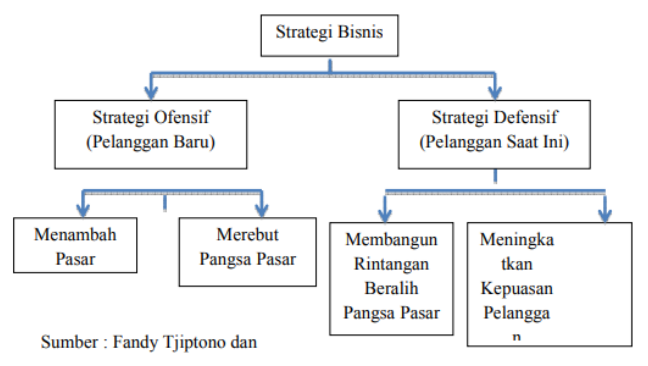

Gregorius Chandra ( $2011: 322$ )

\section{Dimensi untuk mengukur kepuasan pelanggan}

(Kotler et al., 2009) berpendapat bahwa perusahaan akan melakukan kebijakan melalui pengukuruan tingkat kepuasan konsumen dengan berkala dikarenakan salah satu faktor utama agar konsumen dapat bertahan adalah kepuasan pelanggan. (Kotler et al., 2009) menambahkan bahwa upaya agar pelanggan dapat bertahan adalah sesuatu yang penting jika dibandingkan dengan upaya menarik pelanggan. Maka dari itu ada 5 (lima) dimensi yang digunakan dalam pengukuran kepuasan pelanggan, diantaranya:

1. Pembelian berulang-ulang.

2. Memberikan pernyataan yang baik mengenai perusahaan ke orang lainnya dan memberikan rekomendasi.

3. Tidak menaru perhatia produk lainnya atau competitor.

4. Melakukan pembelian produk lainnya yang berasal dari perusahaan yang sama.

5. Memberikan ide-ide produk maupun jasa pada perusahaan.

\section{Pengukuran Kepuasan Pelanggan}

Kotler yang dikutip (Tjiptono \& Chandra, 2011) mengatakan terdapat pendekatanpendekatan yang dapat digunakan perusaan sebagai pengukuruan dan pemantauan tingkat rasa puas penglanggan dan pelanggan competitor. Kotler melakukan identifikasi 4 (empat) pendekatan untuk pengukuran rasa puas pelanggan, diantaranya:

1) Sistem Keluhan dan Saran

2) Ghost Shopping (Mystery Shopping)

3) Lost Customer Analysis

4) Survei Kepuasan Pelanggan

\section{Lembaga Kursus dan Pelatihan}

Lembaga Kursus dan Pelatihan (LKP) yaitu merupakan satu diantara beberpa lembaga pendidikan diluar pendidikan formal (nonformal) yang didirikan dan terselenggara untuk masyarakat yang membutuhkan ilmu dan kapasitas baik sikap, keahlian, kapabiltas yang berguna dalam pengembangan diri, bekerja, usaha mandiri, berprofesi serta untuk meneruskan ke pendidikan selanjutnya yang lebih baik. LKP merupakan satu diantara beberapa wujud bentuk penyelenggaraan pendidikan pada jalur pendidikan diluar pendidikan formal (nonformal) yang 
Lu'lu Ul Maknunah', Endang Astuningtiyas ${ }^{2}$

Pengaruh Kualitas Pelayanan Terhadap Kepuasan Konsumen Lembaga Kursus dan Pelatihan (LKP) Citra Jelita Desa Wonorejo, Kecamatan Srengat, Kabupaten Blitar

memiliki keterkaitan yang dekat dengan pendidikan formal. Pendidikan pada dasarnya tidak hanya diadakan dan diselenggarakan dalam pendidikan formal, akan tetapi terdapat pendidikan lainnya yang diselenggarakan pada pendidikan informal dan nonformal.

Pendidikan formal, informal, dan nonformal saling berhubungan diantara ketiga pendidikan tersebut dan dari ketiga pendidikan itu tidak dapat berjalan sendiri-sendiri. Diantara tiga pendidkan tersebut saling mengisi dan mencupukupi apa yang dibutuhkan dalam pembelajaran serta mengemban pendidikan selama manusia hidup.

Philip H. Coombs menyatakan bahwasanya pendidikan nonformal merupakan seluruh aktivitas pendidikan yang terorganisir, teratur, serta terlaksana di luar sistem pendidikan formal, yang melahirkan jenis-jenis pembelajaran yang diinginkan oleh golongan orang dewasa ataupun anak-anak.

Berdasarkan pengertian itu, maka kesimpulannya adalah LKP merupakan pendidikan nonformal yang dalam tahapan pelaksanaanya memiliki sistem yang melembaga. Pengertian tersebut tersirat makna bahwa setiap pembangunan pendidikan nonformal dibutuhkan strategi yang direncanakan dengan komprehensif, baik berdasarkan kurikulum, sarana dan prasarana, isi program, sumber pembelajaran, sasaran peserta, dan aspek-aspek yang tidak terpisahkan antar satu dengan yang lainnya dalam pendidikan nonformal.

Berhubungan dengan pogram serta pelatihan, (Hasibuan, 2006) berpendapat bahwasanya "Program merupakan suatu macam perencanaan yang detail dan nyata dikarenakan terdapat dan tertulis yang menjadi sasarannya, kebijaksanaannya, prosedurnya, anggarannya, dan waktu pelaksanaannya. Disamping itu, pengertian program terdapat pada Undang-Undang RI Nomor 25 Tahun 2004, mengenai Sistem Perencanaan Pembangunan Nasional, yang mendefinisikan: Program meruapakn sarana kebijakan yang terdapat satu maupun lebih aktivitas yang dijalankan oleh lembaga pemerintah/instansi agar tercapai sasaran serta tujuannya dan mendapatkan pendanaan maupun aktivitas masyarakat yang berkoordinasi dengan lembaga masyarakat.

(Gomes et al., 2003) menjelaskan bahwa "Pelatihan merupakan beberapa upaya agar dapat diperbaiki kinerja pekerjaan pada suatu kegiatan kerja tertentu yang telah menjadi tanggung jawab seseorang. Penyelenggaran pelatihan yang berhubungan dengan proses pembelajaran bertujuan agar membantu peserta pelatihan untuk mendapatkan keahlian, sikap maupun pola pikir serta kualitas waktu yang dimungkinkan untuk sesorang bisa paham terhadap apa yang dikerjakan dan bila melaksanakannya dengan efesien serta memberikan rasa puas."

\section{Ciri-Ciri Dari Lembaga Kursus}

Berikut ini adalah ciri-ciri lembaga kursus, diantaranya sebagai berikut:

1) Konten dan tujuan pendidikan selalu mengarah pada sesuatu yang berhubungan dengan apa yang dibutuhkan oleh masyarakat untuk membangun minat dan bakat, pekerjaan, menyiapkan masa depan, menguatkan aktivitas pendidikan dan meneruskan ketingkat yang lebih tinggi.

2) Pendekatan penyajian yang dipakai selaras dengan keadaan peserta didik dan keadaan lingkungan.

3) Program dan konten pendidikan terkait dengan pengetahuan tentang ilmu keahlian fungsional, profesi, yang dibutuhkan untuk menjalani kehidupan di masyarakat untuk membentuk serta mengembangkan kepribadian, dan agar terpenuhi apa yang dibutuhkan pasar tenaga kerja, dan untuk menyiapkan masa depannya.

4) Usia peserta didik yang tidak terbatas atau tidak memerlukan kesamaan dalam jenjang pendidikan tertentu. 


\section{PUBLICIANA : JURNAL ILMU SOSIAL DAN ILMU POLITIK \\ VOLUME 14, NO 02}

ISSN : 1979 - 0295 / E-ISSN : $2502-7336$

5) Jenis kelamin peserta didik tidak terdapat perbedaan oleh jenis serta tingkatan pendidikan, kecuali jika fisik, mental, budaya maupun sikap dan lingkungan sosialnya tidak memberikan izin.

6) Pendidik, fasilitas dan infrastruktur diadaptasi dengan jenis dan tingkat pelatihan.

7) Hasil pembelajaran langsung dapat digunakan dalam kehidupan sehari-hari.

8) Terdapat kurikulum selaras dengan program pembelajaran yang diperlukan.

\section{Peran Lembaga Kursus dan Pelatihan}

LKP menyediakan bahan pembelajaran yang meliputi seluruh pengetahuan dan ketrampilan yang mempunyai kaitannya dengan elemen-elemen dalam kehidupan sehari-hari. Hal ini ditujukan agar dapat memenuhi segala jenis apa yang dibutuhkan pembelajaran yang mucul didalam kehidupan bermasyarakat. Keberadaan pendidikan nonformal seperti Lembaga Kursus dan Pendidikan (LKP) ini sangat dibutuhkan masayarakat dengan berbagai alasan sebagai berikut:

1) Kebutuhan pendidikan ketrampilan yang tidak terjawab dan didapatkan di pendidikan formal,

2) Kemajuan dan kecanggihan teknologi,

3) Akses pendidikan formal yang terbatas dan terjangkau oleh masyarakat,

4) Adanya permasalahan-permasalahan yang berkaitan terhadap perkembangan serta kehidupan bermasyarakat.

Adapun program pendidikan nonformal dikelompokkan dalam dua hal, yaitu:

1) Program pendidikan dasar yang memberi layanan kepada calon peserta pelatihan

2) Program pendidikan lanjutan yang memberi layanan pendidikan agar dapat membangun serta menambah kapasitas dan keahlian ke jenjang yang lebih tinggi yang belum memiliki kemapuan-kemampuan dasar.

Berdasarkan hal tersebut, LKP adalah satu diantara beberapa pendidikan di luar pendidikan formal yang semakin jelas diperlukan dalam upaya mengembangkan dan melaksanakan pembelajaran sepanjang hayat atau infelong learning. Selain itu juga sebagai:

1. Pelengkap (complement) bahan pembelajaran yang dilaksanakan pada pendidikan formal.

2. Penambah (suplement) bahan pembelajaran yang dilakukan pada pendidikan formal.

3. Lembaga alternatif lainnya yang berdiri dengan sendirinya atau subtituf.

\section{Pengaruh antara Kualitas Pelayanan dengan Kepuasan Konsumen}

Berlandaskan teori yang dipaparkan sebelumnya bisa dipahami bahwasanya untuk mengembangkan dasar yang kuat agar terjalin jalinan yang baik dengan konsumen diperlukan kualitas layanan yang optimal. Pelayanan (services) adalah sesuatu yang tidak bisa diwujudkan dengan seketika tetapi wajib diwujudkan dengan perlahan dan seksama. Pelayanan merujuk pada pelanggan sebagai pemegang sebuah ingatan yang unik dalam ingatan terhadap sebuah produk atau jasa.

Kepuasan konsumen akan meberikan keuntungan untuk. Maka dari itu, terciptanya layanan yang berkualitas merupakan tujuan perusahaan untuk dapat memuaskan konsumen. Ini artinya ada hubungan dimana layanan bisa dipergunakan untuk mengukur tingkatan kepuasan konsumen.

Hal ini selaras dengan apa yang dipaparkan oleh oleh (Kotler \& Amstrong, 2010), yang menyebutkan: "Consumer loyalty is firmly connected to quality. Quality has an immediate impaction item execution and consumer loyalty. In the tightest sense, quality can be characterized as "independence from turncoats" however most client's focused organization go 
Lu'lu Ul Maknunah', Endang Astuningtiyas ${ }^{2}$

Pengaruh Kualitas Pelayanan Terhadap Kepuasan Konsumen Lembaga Kursus dan Pelatihan (LKP) Citra Jelita Desa Wonorejo, Kecamatan Srengat, Kabupaten Blitar

past this limited meaning of value. All things considered, they characterized quality as far as consumer loyalty". (Tauriana \& Arisani, 2012) menyebutkan bahwa layanan memiliki hubungan yang erat erat dengan bisnis jasa yang dilaksanakan melalui pemberian rasa puas dalam melayani pelanggannya. (Dominici \& Guzzo, 2010) mengatakan bahwasanya kepuasan pelanggan pada umumnya memiliki hubungan dengan kualitas layanan dalam kaitannya hubungannya dengan kualitas layanan, kepuasan pelanggan dan retensi pelanggan.

Sedangkan, (Jaiswal, 2008) menyebutkan bahwa ada pengaruh yang positif antara kaitanya kualitas pelayanan dengan kepuasan pelanggan. Berdasarkan kualitas layanan yang didapatkan konsumen adalah sebuah ukuran performa layanan, sehingga memiliki pengaruh terhadap rasa puas dari konsumen. Dalam penelitian tersebut memperlihatkan bahwasanya kepuasan pelanggan adalah variabel yang dipengaruhi kaitannya antara variabel independen dan dependen (variabel intervening) diantara kualitas layanan dan minat membeli berulang. Maka dapat dikatakan kualitas layanan memiliki pengaruh terhadap kepuasan pelanggan, dan kepuasan pelanggan memiliki pengaruh terhadap minat membeli kembali sebagai salah satu cara untuk membuat pelanggan bertahan.

\section{METODE PENELITIAN}

Untuk memperoleh data yang diperlukan, peneliti melakukan kegiatan penelitian pada Lembaga Kursus dan Pelatihan (LKP) Citra Jelita Desa Wonorejo Kecamatan Srengat Kabupaten Blitar. Model penelitan ini, menggunakan pendekatan quantitative research melalui metode deskriptif. Penelitian kuantitatif adalah satu diantara beberapa jenis penelitian yang uraian penajamanya secara analitis, direncanakan dan runtut secara detail dari awal sampai dengan penyusunan rancangan penelitian.

(Sugiyono, 2013) menyebutkan bahwa pendekatan penelitian kuantitatif bisa didefinisikan sebagai pendekatan penelitian yang didasari pada filsafat positivisme, yang dipergunakan untuk penelitian pada suatu sampel tertentu, teknik mengambil sampel biasanya dilaksanakan dengan random, mengmpulkan data dengan instrumen penelitian, analisa dan memiliki sifat kuantitatif atau statistika yang tujuannya untuk melakukan pengujian hipotesa yang sudah ditetapkan. Pada penelitian kuantitatif digunakan metode deskriptif yang tujuannya untuk menjelaskan objek yang diteliti atau hasil penelitian.

Alat bantu untuk mengolah data yang dipergunakan oleh peneliti pada penelitian ini yang melalui software komputer untuk bisa mengelola data penelitian yang efektif dan efisien. Adapun software yang dipergunakan dalam pengolaha data yang diteliti yaitu menggunakan SPSS. (Wahyono, 2014) menyebutkan bahwa software SPSS (Statistical package for Social Science) atau saat ini dikenal dengan Statistical Product and Service Solution adalah satu diantara beberapa software yang biasanya dipakai oleh pengguna komputer untuk mengelola data statistika.

Program ini terdapat program analisa yang cukup tinggi, memiliki interface pada lingkungan grafis dengan pengoperasian yang cukup sederhana sehingga mudah untuk dipahami pemakaiannya. SPSS dapat digunakan untuk membantu pengolahan, perhitungan dan analisis data secara statistik.

Variabel penelitian meruapakan segala sesuatu yang berwujud apapun yang kemudian dijadijkan peneliti untuk diriset sehingga didapatkan informasi mengenai fenomena tersebut, 


\section{PUBLICIANA : JURNAL ILMU SOSIAL DAN ILMU POLITIK \\ VOLUME 14, NO 02}

ISSN : 1979 - 0295 / E-ISSN : $2502-7336$

selanjutnya menarik kedalam kesimpulan. Variabel dapat diartikan juga sebagai atribut dari bidang ilmu ataupun aktivitas tertentu.

Definisi konseptual adalah memberikan pejelasan terhadap istilah yang peneliti pergunakan melalui penggunaan bahasa peneliti. Apabila terdapat pernyataan pakar maupun orang lain, maka peneliti harus tetap memberikan kesimpulan atas pernyataan orang tersebut dengan pendapat peneliti sehingga didapatkan suatu makna istilah yang selaras dengan yang peneliti maksud. Definisi konseptual diantaranya sebagai berikut:

1) Kualitas pelayanan adalah sebuah keadaan dinamis yang berkaitan dengan produk, jasa, manusia, proses serta lingkungan dimana menilai kualitas yang ditetapkan di saat layanan diberikan kepada publik. Pendapat ahli, oleh (Fitzsimmons et al., 2008) menyatakan bahwasanya kualitas layanan adalah sesuatu yang kompleks maka agar dapat ditetnutkan tingkatan kualitas layanan dapat diukur melalui 5 (lima) dimensi, berikut ini:
a) Andal (Reliability)
b) Pertanggungjawaban (Resposiveness),
c) Jaminan (Assurance).
d) Empati (Emphaty)
e) Terjamah (Tangibles)

2) Sedangkan menurut Gronroos (Tjiptono, 2007) menyebutkan bahwasanya terdapat 6 (enam) kriteria utama untuk penilaian kualitas jasa, diantaranya:

a) Profesionalisme dan kemampuan (Profesionalism and skill).

b) Sikap dan kebiasaan (Attitude and behavioral)

c) Aksesibelitas dan fleksibelitas (Accessibility and flecsibility)

d) Keandalan dan kepercayan (Reliability and trustworhtiness)

e) Pemulihan (Recovery)

f) Reputasi dan kredibelitas (Reputation and credibility)

\section{Skala Pengukuran Variabel}

(Sugiyono, 2013) berpendapat bahwa skala Likert dapat dipergunakan sebagai pengukuran sikap, pendapat, ataupun persepsi seseorang atau sekelompok orang mengenai keadaan sosial yang ada. Indikator variabel pada penelitian ini tersusun selaras dengan indicator pada instrumen dan dipaparkan ke bentuk pertanyaan dan pemerian jawaban dari tiap-tiap instrumen. Untuk melakukan pengukuran variabel yakni dengan penggunaan skala Likert yang memperlihatkan jumlah setuju maupun tidak setuju dari jawaban responden. Disetiap pernyataan responden diberikan nilai 1 sampai dengan 5, dan tiap-tiap bobot memiliki skor.

Pada penelitian ini disusun dengan berpedoman skala Likert yang memakai sistem penilaian berikut ini:

- Jika memilih a, maka "Sangat Setuju" dan diberikan bobot 5

- Jika memilih b, maka "Setuju" dan diberikan bobot 4

- Jika memilih c, maka "Cukup Setuju" dan diberikan bobot 3

- Jika memilih d, maka "Kurang Setuju" dan diberikan bobot 2

- Jika memilih e, maka "Sangat Kurang Setuju" dan diberikan bobot 1 
Lu'lu Ul Maknunah', Endang Astuningtiyas ${ }^{2}$

Pengaruh Kualitas Pelayanan Terhadap Kepuasan Konsumen Lembaga Kursus dan Pelatihan (LKP) Citra Jelita Desa Wonorejo, Kecamatan Srengat, Kabupaten Blitar

Populasi pada penelitian ini yaitu orang-orang yang pernah menjalani peserta pelatihan di LKP Citra Jelita. Populasi ini memiliki sifat yang heterogen, hal ini dapat terlihat dari keberagaman usianya, jenis kelaminnya, serta pendidikannya. Jumlah populasi peserta pelatihan selama tahun 2019 sebanyak 110 peserta.

(Sugiyono, 2013) berpendapat bahwa sampel adalah bagian dari seluruh kekhasan yang ada pada populasi itu. Apabila populasi pada perusahaan yang besar, maka peniliti dapat mempergunakan sampel yang didapatkan dari populasi tersebut.

Data yang digunakan bersumber dari dua data berikut ini:

a) Data Primer

(Bungin, 2017) menyebutkan bahwa data primer ialah sumber data yang didapatkan secara langsung dari sumber yang pertama di tuju di tempat penelitian maupun objek yang diteliti. Berdasarkan pendapat tersebut data primer yang digunakan pada penelitian ini adalah langsung kepada peserta pelatihan di LKP Citra Jelita.

b) Data Skunder

Berdasarkan pendapat (Bungin, 2017) data sekunder adalah sumber data yang didapatkan yang berasal dari sumber kedua yang dibutuhkan peneliti. Adapun data sekunder yang digunakan peneliti adalah data eksternal berupa karya ilmiah, jurnal. Dan data internal berupa dokumen pendukung seperti data profil LKP Citra Jelita, Struktur Organisasi dan jumlah peserta pelatihan LKP Citra Jelita

\section{Teknik Pengumpulan Data}

Peneliti menggunakan beberapa cara dalam mengumpulkan data dalam dalam penelitian agar mendapatkan data relevan dan lengkap, diantaranya:

\section{Pengamatan (Observation)}

Observasi yang di lakukan dalam penelitian ini adalah observasi nonpastisipan/ pengamat dalam sebagai partisipan. Maksudnya peneliti sebagai outsider dari komunitas yang akan dilakukan oleh peneliti, melihat dan menyusun catatan lapangan dari jauh. Artinya peniliti tidak terlibat langsung dalam proses kinerja melainkan hanya bertindak sebagai pengamat, karena peneliti tidak menjadi bagian dari objek kajian penelitian.

\section{Kuesioner}

Pada penelitian ini pengumpulan data selanjutnya dilaksanakan melalui pemberian kuesioner ke peserta pelatihan di LKP Citra Jelita.

\section{Dokumentasi (Documentation)}

Adapun untuk sumber bahan tertulis yaitu berupa dokumen resmi, misalnya data absensi/ kehadiran, SOP dan standar kerja LKP Citra Jelita, arsip-arsip tertulis dari Pegawai LKP Citra Jelita. Sedangkan untuk sumber bahan tidak tertulis yaitu peneliti melakukan dokumentasi dengan mengambil gambar pada kegiatan kinerja di LKP Citra Jelita.

\section{Studi Pustaka (Study library)}

Peneliti menggunakan teknik studi pustaka, yakni melalui pengumpulan informasi yang ada pada jurnal ilmiah, buku teks, ataupun karya ilmiah dalam penelitian-penelitian terdahulu. Informasi yang terdapat dalam jurnal ilmiah, buku-buku, maupun karya ilmiah pada penelitian sebelumnya peneliti jadikan sebagai landasan teori untuk membahas masalah yang sedang peneliti kaji dari sisi teori yang berlaku. 


\section{PUBLICIANA : JURNAL ILMU SOSIAL DAN ILMU POLITIK}

VOLUME 14, NO 02

ISSN : 1979 - 0295 / E-ISSN : $2502-7336$

Studi pustaka ini bertujuan untuk mendapatkan fenomen serta agar diketahui konsep pendekatan yang dipergunakan melalui perbandiangan dan penyesuaian diantara teori dengan praktek maupun bisa juga dilaksanakan dengan mengumpulkan data yang bids didapatkan dari beberapa sumber pustakan dengan menggunakan sumber yang ada.

\section{Klasifikasi Variabel}

Ada dua klasifikasi varibel yang digunakan peneliti, diantaranya:

1) Variabel bebas/ variabel independen : Kualitas pelayanan (X)

2) Variabel terikat/variabel dependen : Kepuasa Konsumen (Y)

\section{Metode Analisis Data}

Pngelolaan data pada penelitian kuantitatif, pada umumnya dilaksanakan dengan melalui langkah-langkah diantaranya:

a. Memeriksa (editing)

b. Proses pemberian identitas (coding)

\section{Uji Validitas}

c. Proses pembeberan (tabulating)

Pengujian validitas bertujuan agar dapat dilakukan pengujian instrumen penelitian yang menggambarkan ukuran konstruksi sesuai yang ada pada kerangka teoritis. Dari hasil $\mathrm{r}_{\mathrm{xy}}$ dilakukan perbandingan dengan nilai kritis produk moment $\left(\mathrm{r}_{\text {tabel }}\right)$. Apabila hasil yang didapatkan $r_{x y}>r_{\text {tabel }}$ artinya instrument yang dilakukan pengujian menunjukan kevalidan.

\section{Uji Reliabilitas}

Pengujian realibilitas adalah lanjutan dari pengujian validitas, dimana butir yang ada pada uji ini yaitu item yang telah valid. (Sekaran, 2006) mengatakan bahwa pada uji reliabilitas apabila nilai koefisien $\alpha \leq 0.6$ maka kurang baik, sedangkan untuk koefisien $\alpha \geq 0.6$ sehingga bisa disimpulkan bahwasannya instrumen yang dipergunakan adalah reliabel.

Tabel Kriteria Uji Reliabilitas

\begin{tabular}{|l|l|l|}
\hline NO & Hasil Perhitungan & Derajat Reliabilitas \\
\hline 1 & $n<0,20$ & Derajat reliabilitas sangat rendah \\
\hline 2 & $0,20<n \leq 0,40$ & Derajat reliabilitas rendah \\
\hline 3 & $0,40<n \leq 0,60$ & Derajat reliabilitas sedang \\
\hline 4 & $0,60<n \leq 0,80$ & Derajat reliabilitas tinggi \\
\hline 5 & $0,80<n \leq 1,00$ & Derajat reliabilitas sangat tinggi \\
\hline
\end{tabular}

Sumber: Arikuntoro (2006)

\section{Uji Normalitas}

Untuk menguji normalitas dengan statistika yaitu melalui penggunaan uji KolmogorovSmirnov. Uji Kolmogorov-Smirnov adalah pengujian normalitas yang biasanya diterapkan dikarenakan memiliki kesederhanaan dan tidak menyebabkan berbeda pemahaman. Uji Kolmogorov-Smirnov dilaksanakan melalui tingkatan signifikansi sebesar 0,05. Agar lebih sederhana, uji ini bisa dilaksanakan dengan memperhatikan profitabilitas dari KolmogorovSmirnov Z statistik. Apabila profitabilitas Z statistik kurang dari 0,05, maka nilai residiual pada sebuah regresi tidak berdistribusi normal (Sitinjak \& Ghozali, 2012)

\section{Uji Heterokedastisitas}


Lu'lu Ul Maknunah', Endang Astuningtiyas ${ }^{2}$

Pengaruh Kualitas Pelayanan Terhadap Kepuasan Konsumen Lembaga Kursus dan Pelatihan (LKP) Citra Jelita Desa Wonorejo, Kecamatan Srengat, Kabupaten Blitar

Satu daiantara beberpa cara yang dipergunakan untuk pengujian heterokedastisitas yaitu melalui pengujian Glejser. Uji ini dilaksanakan melalui regresi variabel bebas terhadap nilai absolut residual. Untuk menarik kesimpulan heterokedastisistas melalui kriteria dinilai berdasarkan nilai $t$ dengan probabilitas signifikansi $>0,05$ ini artinya persamaan regresi tersebut tidak terjadi heterokedastisitas. Sebaliknya, apabila nilai t dengan probabilitassig $<0,05$ maka persamaan regresi terjadi heteroskedostisitas.

\section{Uji Hipotesis/Uji T (Parsial)}

Pengujian $\mathrm{T}$ bertujuan agar dapat terlihat pengaruh yang signifikan dari variabel bebas yakni gaya kepemimpinan terhadap variabel terikat yaitu kinerja pegawai. Uji $t$ ini akan penulis gunakan untuk menguji hipotesis. Variabel dependen apabila nilai p-value (sig) lebih kecil dari alpha (confidance interval). Langkah-langkah Uji Hipotesis untuk Koefisien Regresi adalah:

1) Rumusan Hipotesa Nilai $\left(\mathrm{H}_{0}\right)$ serta Hipotesis Alternatif $\left(\mathrm{H}_{\mathrm{a}}\right)$

$\mathrm{H}_{\mathrm{o}}$ : Diduga tidak ada pengaruh kualitas pelayanan terhadap kepuasan konsumen.

$\mathrm{H}_{\mathrm{a}}$ : Diduga ada pengaruh kualitas pelayanan terhadap kepuasan konsumen.

2) Menentukan nilai t tabel yang didasari dari taraf signifikan serta taraf derajat kebebasan:

a) Taraf sig. $=5 \%(0,05)$

b) Derajat kebebasan $=(n-1-k)$

3) Kriteria kuputusan, yaitu:

a) Apabila t hitung $>\mathrm{t}$ tabel, serta sig $<0,05$ kesimpulannya $\mathrm{H}_{\mathrm{o}}$ ditolak dan $\mathrm{H}_{1}$ diterima.

b) Apabila t hitung $<\mathrm{t}$ tabel, serta sig $>0,05$ kesimpulannya $\mathrm{H}_{\mathrm{o}}$ diterima dan $\mathrm{H}_{1}$ ditolak.

\section{HASIL DAN PEMBAHASAN}

Dibawah ini adalah profil dari responden berdasarkan jenis kelaminnya, umurnya dan pekerjaanya.

Tabel Karakteristik Responden Berdasarkan Jenis Kelamin

\begin{tabular}{|l|l|l|}
\hline Jenis Kelamin & Frekuensi & Prosentase (\%) \\
\hline Laki - laki & 2 & $6 \%$ \\
\hline Perempuan & 28 & $94 \%$ \\
\hline Jumlah & $\mathbf{3 0}$ & $\mathbf{1 0 0 \%}$ \\
\hline
\end{tabular}

Dari tabel di atas memperlihatkan jumlah responden yang melakukan pengaduan di LKP Citra Jelitas yaitu berjumlah 2 orang (6\%) dan Perempuan berjumlah 28 orang (94\%). Data ini menunjukkan sebagian besar dari konsumen Lembaga Citra Jelita adalah perempuan. 
PUBLICIANA : JURNAL ILMU SOSIAL DAN ILMU POLITIK

VOLUME 14, NO 02

ISSN : 1979 - 0295 / E-ISSN : $2502-7336$

Tabel Karakteristik Responden Berdasarkan Umur

\begin{tabular}{|l|l|l|}
\hline Umur & Frekuensi & $\%$ \\
\hline $15-25$ & 18 & $60 \%$ \\
\hline $26-35$ & 8 & $26 \%$ \\
\hline $36-45$ & 4 & $14 \%$ \\
\hline Jumlah & $\mathbf{3 0}$ & $\mathbf{1 0 0} \%$ \\
\hline
\end{tabular}

Tabel di atas memperlihatkan bahwasannya jumlah sampel dari karakteristik umur yakni 15 - 25 tahun terdapat 18 responden (60\%), umur 26 - 35 tahun berjumlah 8 responden (26\%), umur 36 - 45 tahun berjumlah 4 responden (14\%). Data ini menunjukkan responden sebagian besar usia rata rata masih muda, dengan usia antara $15 \mathrm{sd} 25$ tahun.

\section{Uji Validitas}

Pengukuran validitas dari kuesioner yang disebar kepada responden menggunakan persamaan korelasi. Validitas suatu butir pertanyaan terlihat didalam hasil luaran dari software SPSS pada tabel Pearson Correlation. Menurut (Saputro \& Arikunto, 2018) melihat kevalidan tiap-tiap butir pertanyaan bisa memperhatikan nilai $r$ hitung yang dibandingkan dengn nilai $r$ tabel yaitu nilai $r$ hitung > nilai $r$ tabel. Responden yang digunakan yaitu sejumlah 30 orang. Hasil pengujian validitas variabel penelitian Kualitas Pelayanan (X) dan variabel penelitian Kepuasan Maysrakat (Y) terlihat di tabel di bawah ini:

\section{Tabel Uji Validitas Untuk Variabel Penelitian Kualitas Pelayanan (X)}

\begin{tabular}{|l|l|l|l|}
\hline No. Item & Nilai sig (2-tiled) & $\alpha=0,05(5 \%)$ & Keterangan \\
\hline Item 1 & 0.000 & 0,05 & Valid \\
\hline Item 2 & 0.002 & 0,05 & Valid \\
\hline Item 3 & 0.000 & 0,05 & Valid \\
\hline Item 4 & 0.009 & 0,05 & Valid \\
\hline Item 5 & 0.000 & 0,05 & Valid \\
\hline
\end{tabular}

Sumber: Data Primer Diolah 2020

Berlandaskan dari tabel diatas, bahwa variabel penelitian dan kualitas pelayanan hasil nilai $\alpha$ yaitu 0,05 (didasari pada tabel Correlations pada output SPSS). Maka dari itu, semua butir pernyataan di tiap-tiap variabel didapatkan nilai signifikan denga nilai 0,000, atau lebih kecil dari nilai probabilitas $(\alpha)$ yaitu 0,05 . Maka semua butir pertannyaan dapat dikatakan mempunyai korelasi yang positif dan signifikan. Sehingga kesimpulannya adalah semua butir sudah terpenuhi persayaratan dikatakan valid. 
Lu'lu UI Maknunah', Endang Astuningtiyas ${ }^{2}$

Pengaruh Kualitas Pelayanan Terhadap Kepuasan Konsumen Lembaga Kursus dan Pelatihan (LKP) Citra Jelita Desa Wonorejo, Kecamatan Srengat, Kabupaten Blitar

Tabel Uji Validitas Variabel Penelitian Kepuasan Konsumen (Y)

\begin{tabular}{|l|l|l|l|}
\hline No. Item & Nilai sig (2-tiled) & $\alpha=0,05(5 \%)$ & Keterangan \\
\hline Item 1 & 0.000 & 0,05 & Valid \\
\hline Item 2 & 0.002 & 0,05 & Valid \\
\hline Item 3 & 0.002 & 0,05 & Valid \\
\hline Item 4 & 0.006 & 0,05 & Valid \\
\hline Item 5 & 0.000 & 0,05 & Valid \\
\hline Item 6 & 0.041 & 0,05 & Valid \\
\hline
\end{tabular}

Sumber: Data Primer Diolah 2020

Dari hasil pengujian validitas variabel kepuasan konsumen pada tabel diatas bahwasannya hasil nilai $\alpha$ yaitu 0,05 (berdasarkan tabel Correlations pada output SPSS). Maka dari itu, semua butir pernyataan tiap-tiap variabel didapatkan nilai signifikan yang lebih kecil dari probabilitas $(\alpha)$ yaitu 0,05 . Artinya semua butir pertanyaan dapat dikatakan mempunyai korelasi yang positif dan signifikan. Maka dapat disimpulkan bahwa, Sehingga kesimpulannya adalah semua butir sudah terpenuhi persayaratan dikatakan valid.

\section{Uji Reliabilitas}

Menurut (Saputro \& Arikunto, 2018) dalam pengujian reliabilitas apabila hasil Cronbach's Alpha (koefisien $\alpha$ ) $\leq 0.6$ yaitu kurang baik, kebalikannya jika hasil Cronbach's Alpha (koefisien $\alpha$ ) $\geq 0.6$, maka dinyatakan bahwasannya instrumen yang dipergunakan adalah reliabel. Untuk hasil pengujian reliabilitas terlihat pada tabel di bawah ini:

Tabel Uji Reliabilitas Variabel Kualitas Pelayanan (X) Reliability Statistics

\begin{tabular}{|l|l|}
\hline $\begin{array}{l}\text { Cronbach's } \\
\text { Alpha }\end{array}$ & N of Items \\
\hline .635 & 5 \\
\hline
\end{tabular}

Sumber: Data Primer Diolah 2020

\section{Tabel Uji Reliabilitas Variabel Kepuasan Konsumen (Y)} Reliability Statistics

\begin{tabular}{|l|l|}
\hline Cronbach's Alpha & N of Items \\
\hline 617 & 6 \\
\hline
\end{tabular}

Sumber: Data Primer Diolah 2020

Dari tabel pengujian reliabilitas pada tabel tersebut, terlihat bahwa hasil Cronbach's Alpha variabel kualitas pelayanan yaitu $0,635 \geq 0,6$ dapat dinyatakan reliabel. Sedangkan pada variabel kepuasan konsumen hasil Cronbach's Alpha yaitu 0,617 $\geq 0,6$ dapat dinyatakan reliabel. Sehingga, dalam penelitian ini seluruh variabel yakni Kualitas Pelayanan (X) serta Kepuasan konsumen (Y) dikatakan reliabel.

\section{Uji Normalitas}

Pengujian Kolmogorov-Smirnov merupakan pengujian normalitas yang biasanya diterapkan dikarenakan memiliki kesederhanaan dan tidak menyebabkan berbeda persepsi. 
PUBLICIANA : JURNAL ILMU SOSIAL DAN ILMU POLITIK

VOLUME 14, NO 02

ISSN : 1979 - 0295 / E-ISSN : $2502-7336$

(Sitinjak \& Ghozali, 2012) mengatakan bahwa uji Kolmogorov-Smirnov dilaksanakan melalui tingkat signifikansi yaitu 0,05. Uji normalitas memiliki tujuan agar dapat melakukan pengujian apakah pada model regresi, variabel dependen serta independen kedua-duanya terdistribusi normal ataupun tidak. Uji statistik non-parametrik yang dipergunakan yaitu pengujian Kolmogorov smirnov. Jika sebuah model regresi memiliki niliai signifikansi lebih besar dari 0,05 maka dapat dikatakan model regresi tersebut memiliki distribusi normal (Chariri \& Ghozali, 2007) Untuk hasil pengujian normalitas terlihat pada tabel di bawah ini:

\section{Tabel Uji Normalitas}

\begin{tabular}{l} 
One-Sample Kolmogorov-Smirnov Test \\
\begin{tabular}{|ll|l|}
\hline \multicolumn{2}{|l|}{} & $\begin{array}{l}\text { Unstandardize } \\
\text { d Residual }\end{array}$ \\
\hline $\mathrm{N}$ & Mean & 30 \\
Normal Parameters ${ }^{\mathrm{a}, \mathrm{b}}$ & -0000000 \\
& Std. Deviation & 1.64086380 \\
Most Extreme Differences & Absolute & .085 \\
& Positive & .076 \\
& Negative & -.085 \\
Kolmogorov-Smirnov Z & .468 \\
Asymp. Sig. (2-tailed) & .981 \\
\hline a. Test distribution is Normal. \\
b. Calculated from data.
\end{tabular} \\
\hline
\end{tabular}

Sumber: Data Primer Diolah 2020

Berdasarkan tabel diatas hasil pengujian Kolmogorov smirnov menghasilkan nilai Asymp. Sig. (2-tailed) dengan nilai 0,981 Oleh karena itu nilai sig. (2-tailed) >0,05 sehingga dapat dinyatakan data berdistribusi normal.

\section{Uji Heterokedastisitas}

Pengujian heteroskedastisitas penelitian ini menggunakan teknik uji glejser. Menurut Juliandi et. al (2014) Uji glejser ditentukan oleh nilai signifikasi (Sig.). Apabila hasil signifikasi $>0,05$ maka tidak terdapat heteroskedastisitas, tetapi apabila hasil signifikasi $<0,05$ maka terdapat heteroskedastisitas. Untuk hasil dari pengujian heteroskedastisitas bisa dilihat pada tebel di bawah ini:

Tabel Uji Heterokedastisitas

\begin{tabular}{|c|c|c|c|c|c|c|}
\hline \multirow{2}{*}{\multicolumn{2}{|c|}{ Model }} & \multicolumn{2}{|c|}{$\begin{array}{l}\text { Unstandardized } \\
\text { Coefficients }\end{array}$} & \multirow{2}{*}{\begin{tabular}{|l|} 
Standardized \\
Coefficients \\
Beta \\
\end{tabular}} & \multirow[b]{2}{*}{$\mathrm{t}$} & \multirow[b]{2}{*}{ Sig. } \\
\hline & & $B$ & Std. Error & & & \\
\hline 1 & $\begin{array}{l}\text { (Constant) } \\
\text { Kualitas } \\
\text { Pelayanan }\end{array}$ & $\begin{array}{l}1.879 \\
-.030\end{array}$ & $\begin{array}{l}2.069 \\
.100\end{array}$ & -.057 & $\begin{array}{l}.908 \\
-.302\end{array}$ & $\begin{array}{l}.372 \\
.765\end{array}$ \\
\hline
\end{tabular}

a. Dependent Variable: Abs_Res

Sumber: Data Primer Diolah 2020 
Lu'lu Ul Maknunah', Endang Astuningtiyas ${ }^{2}$

Pengaruh Kualitas Pelayanan Terhadap Kepuasan Konsumen Lembaga Kursus dan Pelatihan (LKP) Citra Jelita Desa Wonorejo, Kecamatan Srengat, Kabupaten Blitar

Dari tabel diatas pengujian heterokedastisitas pada penelitian ini, terlihat bahwasannya hasil untuk signifikannya yaitu $0,765>0,05$, sehingga tidak adanya heteroskedastisitas. Maka kesimpulannya yaitu tidak terjadi heteroskedastisitas atau penelitian ini homoskesdastisitas.

\section{Uji Pengaruh Parsial (Uji T)}

Uji $\mathrm{T}$ atau disebut juga sebagai pengujian parsial, yaitu untuk melakukan pengujian seberapa tingkat pengaruhnya tiap-tiap variable bebas secara tersendiri kepada variable terikat. Uji ini bisa dijalankan melalui perbandingan antara $t$ hitung dan $t$ tabel ataupun melalui pengamatan terhadap kolom signifikan pada tiap-tiap $t$ hitung. Uji $\mathrm{T}$ dipergunakan dalam pengujian tingkatan signifikansi koefisien regresi variabel independen (X) kepada variabel dependen (Y). Kriteria dalam uji ini (Nugroho, 2005), yaitu:

1. Taraf signifikasi $(\alpha=0,05)$

2. Jika $t$ hitung $>\mathrm{t}$ tabel, serta sig $<0,05$ kesimpulannya $\mathrm{H}_{\mathrm{o}}$ ditolak dan $\mathrm{H}_{1}$ diterima.

3. Jika $t$ hitung $<\mathrm{t}$ tabel, serta sig $>0,05$ kesimpulannya $\mathrm{H}_{\mathrm{o}}$ diterima dan $\mathrm{H}_{1}$ ditolak Hasil uji $\mathrm{T}$ dapat dilihat pada tabel berikut:

Tabel Uji T

Coefficients $^{\mathrm{a}}$

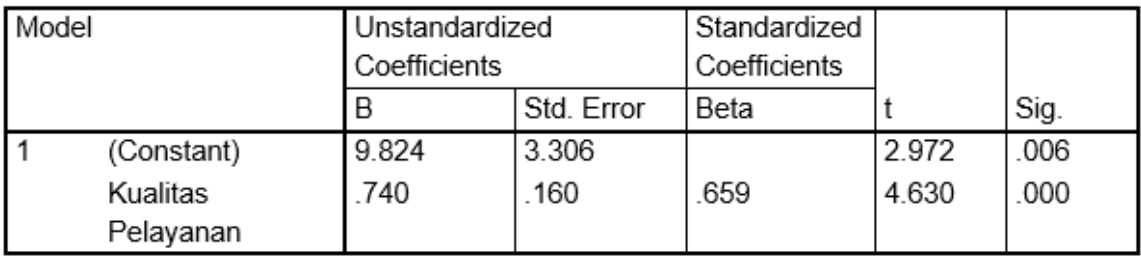

a. Dependent Variable: Kepuasan Konsumen

Sumber: Data Primer Diolah 2020

Dari tabel uji $\mathrm{T}$ diatas, dapat terlihat bahwasannya $\mathrm{t}$ hitung lebih besar dari pada $\mathrm{t}$ tabelnya, yaitu signifikasi $0,000 \leq$ dari 0,05 . Sehingga, dalam penelitian ini $\mathrm{H}_{\mathrm{a}}$ diterima dan $\mathrm{H}_{0}$ ditolak. Maka, kesimpulannya dalam penelitian ini adalah kualitas pelayanan (X) memiliki pengaruh signifikan terhadap kepuasan konsumen (Y).

\section{KESIMPULAN}

Penelitian ini memiliki tujuan agar dapat diketahui apakah terdapat pengaruhnya antara kualiatas kerja dan kepuasan konsumen pada LKP Citra Jelita Kabupaten Blitar. Dari hasil penelitian yang telah terlaksana melalui penggunaan rumus Regresi Linier, hasil perhitungan mengatakan dan memberi deskripsi bahwasannya Kualitas Pelayanan terdapat pengaruhnya yang searah dan sama besarnya terhadap Kepuasan konsumen. Dari pengujian Parsial (T) pada variabel Kualitas pelayanan yaitu 4,630 dengann signifikansi $0,000<0,05$, hal ini menunjukkan bahwa dalam penelitian ini $\mathrm{H}_{\mathrm{a}}$ (Diduga ada pengaruh Kualitas Pelayanan Terhadap Kepuasan konsumen) diterima dan $\mathrm{H}_{0}$ (Diduga tidak ada pengaruh Kualitas Pelayanan Terhadap Kepuasan konsumen) ditolak. Dengan demikian, variabel kualitas layanan berpengaruh positif dan signifikan atas kepuasan konsumen. Artinya variabel kualiatas layanan semakin baik, maka akan meningkatkan kepuasan konsumen.

Dari hasil penelitian diatas bahwasannya untuk mengembangkan dasar yang kuat untuk terhubung jalinan yang baik terhadap konsumen maka membutuhkan kualitas ayanan yang memiliki kualitas yang baik. Pelayanan (services) adalah sesuatu yang tidak bisa diwujudkan dengan seketika tetapi wajib diwujudkan dengan perlahan dan seksama. Pelayanan merujuk pada 


\section{PUBLICIANA : JURNAL ILMU SOSIAL DAN ILMU POLITIK \\ VOLUME 14, NO 02}

ISSN : 1979 - 0295 / E-ISSN : $2502-7336$

pelanggan sebagai pemegang sebuah ingatan yang unik dalam ingatan terhadap sebuah produk atau jasa.

Kepuasan konsumen akan meberikan keuntungan untuk. Maka dari itu, terciptanya layanan yang berkualitas merupakan tujuan perusahaan untuk dapat memuaskan konsumen. Ini artinya ada hubungan dimana layanan bisa dipergunakan untuk mengukur tingkatan kepuasan konsumen.

Hal ini selaras dengan apa yang dipaparkan oleh oleh Kotler, Keller dan Armstrong (2010: 7), yang menyebutkan: "Consumer loyalty is firmly connected to quality. Quality has an immediate impaction item execution and consumer loyalty. In the tightest sense, quality can be characterized as "independence from turncoats" however most client's focused organization go past this limited meaning of value. All things considered, they characterized quality as far as consumer loyalty". Berdasarkan pengertian tersebut dapat dikatakan bahwa apabila sebuah perusahaan yang misa mewujudkan kualitas layanan maka dapat terpenuhi ataupun melebihi dari apa yang diinginkan pelanggan, maka bisa disebut bahwa perusahaan tersebut telah bisa memberikan kepuasan pelanggan serta bisa juga disebut sebagai perusahaan yang memiliki kualitas yang baik.

Penelitian tersebut selaras dengan penelitian yang dilakukan oleh Jentot Tugiyono Suharyanto (2020) dengan judul "Kualitas Pelayanan Dan Pengaruhnya Terhadap Kepuasan Peserta Kursus LKP Pramidia Bandung". Pada penelitian tersebut variabel bebasnya yaitu kualitas pelayanan, terdiri dari lima dimensi (andal, peka, memberikan jaminan, empati serta bukti fisik) dan variabel terikat yaitu rasa puas peserta pelatihan. Data yang dikumpulkan sejumlah 55 orang yang merupakan peserta pelatihan. Keterkaitan diantara variabel penelitian menggunakan regresi linier sederhana. Hasil yang didapatkan memperlihatkan bahwa variabel kualitas pelayanan memiliki pengaruh kepuasan peserta pelatihan dengan jumlah 64,3\% dan $35,7 \%$ terpengaruh oleh variabel lainnya. Model persamaan hubungan dengan rumus linier yang dibentuk yaitu $\mathrm{Y}=0,841 \mathrm{X}+0,674$, yang mana $\mathrm{Y}$ : kepuasan peserta kursus atau pelatihan serta $\mathrm{X}$ : kualitas layanan.

LKP Citra jelita memiliki banyak konsumen baik konsumen pelanggan salon maupun konsumen peserta didik. Dengan banyaknya konsumen yangada, maka perbedaan karakter konsumenpun bermunculan, mulai dariperbedaan karakter, tingkat pendidikan, tingkat pemahaman materi, perbedaan lingkungan yang ada membuat pelayannan juga berbeda pula. Dan untuk mengatasi permaslahan yang ada, LKP Cita Jelita sudah menyiapkaninstruktur dan pelayanan salon yang sangat kompeten, sehingga instrukturdan pelayan salon bisa mengatasi berbagai permasalahan yang ada.

Dengan menggunakan tata bahasa yang baik dan juga cara komunikasi yang santun, sehingga bisa mengimbangi perbedaan konsumen yang beragam. Selain itu ada tahapan-tahapan yang dapat dilaksanakan di lokasi kerja supaya keanekaragaman dijadikan sebagai motivasi agar menjadi kreatif serta produktif, antara lain:

1) Mengenali jenis keragaman

Keragaman dan perbedaan saat di lokasi dimana bekerja memiliki beragam bentuk serta berbeda dari satu lokasi ke lokasi yang lain. Tiap-tiap orang yang melaksanakan pekerjaan pada suatu kantor harus mengetahui apa saja yang membedakan dan beragam yang ada, contohnya: berbeda agama, ras, suku, dan lain-lain. Jika telah diketahui jenis keragaman 
Lu'lu Ul Maknunah', Endang Astuningtiyas ${ }^{2}$

Pengaruh Kualitas Pelayanan Terhadap Kepuasan Konsumen Lembaga Kursus dan Pelatihan (LKP) Citra Jelita Desa Wonorejo, Kecamatan Srengat, Kabupaten Blitar

di lokasi bekerja, makan akan memudahkan untuk penentuan langkah selanjutnya agar tetap menjaga keragaman.

2) Memiliki sikap sopan

Tak ada pendekatan yang lebih baik untuk menjaga keragaman dibanding dengan tindakan uang tenang serta sopan. Melalui sikap kesopanan dan kesantunan, maka orang lain juga akan berbuat sopan. Jika semua orang berada di tempat di mana orang tersebut bekerja dengan menanamkan sifat sopan, baik dengan peimpinan atau bawahannya, maka perbedaan tersebut tidak akan terasa. Selain itu, ketenangan dan selalu mau mendengarkan dapat membuat kondisi menjadi tenang. Setiap orang memiliki karakter dan sifat yang berbeda, tetapi konflik akan lebih cepat jika semua orang berbicara kuat dan saling menyalahkan. Mencoba untuk selalu mendengarkan pendapat orang lain, bahkan jika bertentangan pendapat, maka seharusnya tetap mendengarkan, melalui sikap tersebut maka orang tersebut menghargai pendapat orang lain. Selalu bersikap penuh keramahan melalui senyum dan menyapa satu sama lain meskipun pekerjaan lain.

\section{DAFTAR PUSTAKA}

Abdullah, D., \& Rozario, F. (2009). Influence of service and product quality towards customer satisfaction: A case study at the staff cafeteria in the hotel industry. World Academy of Science, Engineering and Technology, 53, 185-190.

Ariani, M. (2003). Arah, kendala dan pentingnya diversifikasi konsumsi pangan di Indonesia. Bungin, B. (2017). Quantitative research methodology. Jakarta: PT Fajar Interpratama Mandiri. Chariri, A., \& Ghozali, I. (2007). Teori akuntansi. Semarang: Badan Penerbit Universitas Diponegoro.

Dominici, G., \& Guzzo, R. (2010). Customer satisfaction in the hotel industry: A case study from Sicily. International Journal of Marketing Studies, 2(2), 3-12.

Fitzsimmons, J. A., Fitzsimmons, M. J., \& Bordoloi, S. (2008). Service management: Operations, strategy, and information technology. McGraw-Hill New York.

Gomes, J., Kogan, L., \& Zhang, L. (2003). Equilibrium cross section of returns. Journal of Political Economy, 111(4), 693-732.

Hasibuan, M. S. P. (2006). Dasar-dasar perbankan. Jakarta: Bumi Aksara.

Jaiswal, A. K. (2008). Customer satisfaction and service quality measurement in Indian call centres. Managing Service Quality, 18(4), 405-416.

Javadein, S. R. S., Khanlari, A., \& Estiri, M. (2008). Customer loyalty in the sport services industry: the role of service quality, customer satisfaction, commitment and trust. Journal of Human Sciences, 5(2).

Jhons, O. (1992). Administración por calidad Total. México, Editorial McGraw-Hill Interamericana.

Kotler, P. (2000). Marketing management: The millennium edition (Vol. 199). Prentice Hall Upper Saddle River, NJ.

Kotler, P., \& Amstrong, G. (2010). Principles of marketing, Jil. 1, Jakarta. Penerbit: Erlangga.

Kotler, P., Keller, K. L., \& Lu, T. (2009). Marketing management in China. Prentice Hall.

Parasuraman, A., Zeithaml, V. A., \& Berry, L. (1988). SERVQUAL: A multiple-item scale for measuring consumer perceptions of service quality. 1988, 64(1), 12-40. 
PUBLICIANA : JURNAL ILMU SOSIAL DAN ILMU POLITIK

VOLUME 14, NO 02

ISSN : 1979 - 0295 / E-ISSN : $2502-7336$

Saputro, E. P., \& Arikunto, S. (2018). Keefektifan manajemen program pembelajaran BIPA (Bahasa Indonesia bagi Penutur Asing) di kota Yogyakarta. Jurnal Akuntabilitas Manajemen Pendidikan, 6(1), 122-138.

Sekaran, U. (2006). Metodologi Penelitian Bisnis Buku 1.

Sitinjak, E. L. M., \& Ghozali, I. (2012). The investor Indonesia behavior on stock investment decision making: Disposition effect, cognition and accounting information. Psychology, $3(8)$.

Stanton, J. F., \& Gauss, J. (1994). Analytic energy derivatives for ionized states described by the equation-of-motion coupled cluster method. The Journal of Chemical Physics, 101(10), 8938-8944.

Sugiyono, D. (2013). Metode penelitian pendidikan pendekatan kuantitatif, kualitatif dan $R \& D$.

Sureshchandar, G. S., Rajendran, C., \& Anantharaman, R. N. (2002). The relationship between service quality and customer satisfaction-a factor specific approach. Journal of Services Marketing.

Tauriana, D., \& Arisani, N. M. D. (2012). Analisis Implementasi Customer Relationship Management dan Kualitas Pelayanan Jasa terhadap Kepuasan Pelanggan dan Dampaknya pada Retensi Pelanggan Hotel Bidakara Jakarta. Binus Business Review, 3(1), 449-460.

Tjiptono, F. (2004). Kepuasan dalam pelayanan. Jakarta: Salemba Empat.

Tjiptono, F. (2007). Strategi Pemasaran, edisi kedua. Yogyakarta: Andi.

Tjiptono, F. (2012). Service Management Mewujudkan Layanan Prima, Edisi 2. Yogyakarta: Andi.

Tjiptono, F., \& Chandra, G. (2006). Manajemen pelayanan jasa. Penerbit Andi, Yogyakarta. Tjiptono, F., \& Chandra, G. (2011). Service, quality \& satisfaction.

Wahyono, T. (2014). Analisis Statistik Mudah dengan SPSS 20. Elex Media Komputindo. 